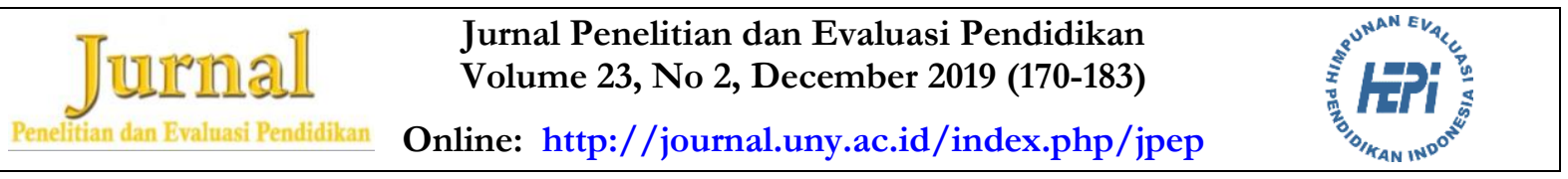

\title{
THE EFFECTIVENESS AND CONSTRAINTS OF LEARNING IN POLYTECHNIC EDUCATION
}

\author{
I Nyoman Gunung \\ Politeknik Negeri Bali \\ I Ketut Darma \\ Politeknik Negeri Bali
}

\begin{abstract}
This study is aimed at finding out: (1) the level of effectiveness of the teaching implementation at a polytechnic education institution viewed from the interrelatedness of the components of context, input, process, and product, and (2) the constraints in the teaching implementation at the institution. This study used the Contex Input Process Product (CIPP) model from Stufflebeam. The data were collected using a questionnaire, interview guide, and related documents. The subjects of the evaluation were the students, lecturers, and the top management staff of the departments at the polytechnic. The data were analyzed using a quantitative descriptive method. The effectiveness of the learning program is determined based on the results of the prototype verification in the Glickman quadrant. The results of the analysis show that the teaching program implementation at the polytechnic viewed from the interrelatedness of context, input, process, and product is considered effective enough. The constraints in the implementation of teaching at the polytechnic are in teaching planning, implementation of semester teaching plans, curriculum, and infrastructure as well as facilities. Those constraints create other barriers to the achievement of learning outcomes, both academic and non-academic.
\end{abstract}

Keywords: program evaluation, effectiveness, constraints, CIPP

Permalink/DOI: http://dx.doi.org/10.21831/pep.v23i2.23526

\section{Contact: I Nyoman Gunung}

nyomangunung@pnb.ac.id

Department of Mechanical Engineering, Politeknik Negeri Bali

Jl. Kampus Bukit Jimbaran, Kuta Selatan, Badung 80364, Bali, Indonesia 


\section{Introduction}

Education is known as a deliberate activity process done to the input according to the predetermined goal. As a process, the results must be evaluated to find out the effectiveness of the teaching and learning process that has been implemented.

In the educational process, evaluation is one of the essential components that play an essential role in identifying the success of an educational program. The evaluation is aimed at obtaining data on the distance between the existing situation and the expected situation using certain criteria. Gronlund and Linn (1990) state that the evaluation of instruction is a process of collecting, analyzing, and interpreting information systematically to determine to what extent the objective of education has been attained. The components that need to be evaluated are students, teachers/lecturers, course materials, curriculum, infrastructure, and facilities.

Evaluation is an effort in deciding the attainment quality of the goal of the program and the students' performance and ability (Ebel \& Frisbie, 1991). To find out an appropriate evaluation system or model, it is important to provide accurate information for the stakeholders, especially the top management of the institution and to optimally enhance the teaching program.

Many evaluation models have been developed by experts and can be used to evaluate the teaching program, one of which is the CIPP evaluation model that was developed by Stufflebeam, et al. 1971 (Arikunto, 2009). Each of the models has a different orientation and approach. To know if the selection of a particular model is appropriate or not, it depends on the type of activity evaluated, whether the program is in the form of activity process, services, or general services.

Stufflebeam, et al. developed the context, input, process, and product (CIPP) model in 1971 (Stufflebeam, 2003). This model is an evaluation model that is oriented toward decision making (a decisionoriented evaluation approach) to help the administrators or leaders in the decision making in the process. Its point of departure is the view that success in an educational program is determined by various factors such as the learner and environmental characteristics, the equipment used, the procedure, and the mechanism of the program implementation. The result will give an alternative solution to the problems faced by the decision-makers (Stufflebeam \& Coryn, 2014).

The CIPP model considers four dimensions: context, input, process, and product. The uniqueness of the model is that it is a type of evaluation related to the decision-makers which concerns with the planning and operation of a program. This model also views the program under evaluation as a system and forms an evaluation model that has some advantages compared to other evaluation models (Forouzandeh, Riazi, \& Sadighi, 2008; Sukardi, 2014; Zhang et al., 2011). The advantages are: (1) it gives a very detailed description of a project, (2) it has the potentiality for use in the area of formative and summative evaluation, (3) it is more comprehensive in filtering information, and (4) it is capable of giving a good basis in making decisions and policies in writing a further program. Another advantage is that the CIPP model provides a comprehensive evaluation format in every stage of evaluation.

The CIPP evaluation model is designed to evaluate just certain aspects, but it can be used comprehensively to see various things related to a program to improve programs, including a development program. The CIPP evaluation model approach is representative enough in probing things related to the implementation of a program. The CIPP evaluation model can be used structurally and significantly. It can evaluate the effectiveness of the assessment formatively and summatively, and also has the ability in solving problems that occur (Hasan, Yasin, \& Yunus, 2015).

The result of the CIPP evaluation model can be used as the basis for making decisions in four types of decision making: 
(1) planning (that influences the selection of the objective of the activity), (2) structuring (that influences the optimal strategy and design of the procedures in attaining the objective), (3) implementation (that provides tools for implementing the program and improving the existing program), and (4) recycling (whether a program of activity needs to be continued, changed, or stopped).

The evaluation of the setting (context evaluation) will produce information on the need (to what extent deviations have occurred between what is expected and what has been realized through the activity program). The evaluation of the supporting capacity (input evaluation) stresses on the provision of information on the strengths and weaknesses of the strategy and procedure that have been selected in the effort to achieve the predetermined objective. Process evaluation stresses on the "what" activity that has been done in the program, "who" the persons appointed as the persons in charge, and "when" the activity will end. On the other hand, product evaluation stresses on to what extent the result that has been attained is in accordance with the desired objective, and whether an activity needs to be stopped, continued, improved, etc. Product evaluation is aimed at relating information on the result to the objective, setting, and process that has been determined, supporting capacity, and process that has been determined beforehand in the program implementation (Arikunto, 2009; Stufflebeam \& Shinkfield, 2007). Many researchers have shown the effectiveness of the CIPP evaluation model for evaluating educational program and training program (Ariawan, Sanjaya, \& Divayana, 2016; Arikunto, 2009; Waluyati, 2012). The result of the CIPP evaluation can give some guidance on what has been done and what has not been done, whether the teaching process that has been designed and the materials given by the teacher can be understood by the students, and are in accordance with the content standard of the teaching implementation.
A school or college as a system is composed of the components of context, input, process, output, and outcome. Context influences input, input process, process output, and output outcome. In a system, there are formed some subsystems that are in a synergy supporting each other in the attainment of a program (Nasution, 2001).

Politeknik Negeri Bali, or Bali State Polytechnic (BSP) is a vocational educational institution in Bali. Its vision is to become a leading college that produces professional graduates with an international competitive advantage in 2025, while one of its missions is to prepare reliable human resources oriented toward the market demand in engineering and commerce with tourism as its superior field, in an effort to improve, modify, and terminate the program. In its progress, there is a need to evaluate in a comprehensive, systematical, and diagnostically way the planning and implementation of the program, involving the teaching staffs at BSP. This evaluation finds out whether the implementation of the teaching has been oriented toward the national standard of education as stipulated by the Regulation of the Minister of Education and Culture No. 49 of 2014 about the national standard of higher education. The appropriate model of evaluation uses the one developed by Stufflebeam, that is, on the components of context, input, process, and product (CIPP).

\section{Research Method}

This study is an evaluation research using the CIPP model conducted at BSP in 2017-2018. The subjects of the study consisted of all the polytechnic members: heads of departments, lecturers, students, administration staffs, and technicians, determined by Krejcie and Nomogram Harry King's table based on a 5\% error (Sugiyono, 2012) The sample for the context, input, and process is 172 people. As for the product, there were 337 students.

The data were collected using context, input, process, and also product instruments that have been proven to have 
high levels of validity and reliability. The level of the content validity of each instrument at the minimum was 0.60 , and that of the highest was 0.90 . The data that have been collected were analyzed quantitativedescriptively using Z-Score and T-Score as follows (Arikunto, 2012) Tscore $=50+10 \mathrm{Z}$ and $Z_{\text {scor }}=\frac{x-M}{S D}$ (Sudjana, 2012).

The data from the result of analysis from each variable were compared to the real mean. Then, they were classified based on their tendency into five categories with the ideal normal curve theoretic norm, as follows (Mardapi, 2012).

$$
\begin{aligned}
& \mathrm{Mi}+1.5 \mathrm{SDi}<\mathrm{x} \leq \mathrm{Mi}+3 \mathrm{SDi} \text { (very high) } \\
& \mathrm{Mi}+0.5 \mathrm{SDi}<\mathrm{x} \leq \mathrm{Mi}+1.5 \mathrm{SDi} \text { (high) } \\
& \mathrm{Mi}-0.5 \mathrm{SDi}<\mathrm{x} \leq \mathrm{Mi}+0.5 \mathrm{SDi} \text { (medium) } \\
& \mathrm{Mi}-1.5 \mathrm{SDi}<\mathrm{x} \leq \mathrm{Mi}-0.5 \mathrm{SDi} \text { (low) } \\
& \mathrm{Mi}-3 \mathrm{SDi}<\mathrm{x} \leq \mathrm{Mi}-1.5 \mathrm{SDi} \text { (very low) }
\end{aligned}
$$

\section{Notes:}

$\mathrm{Mi}=1 / 2($ maximum score + minimum score $)$ $\mathrm{SDi}=1 / 6$ (maximum score - minimum score $)$

The effectiveness of the program implementation in each variable was classified with the percentage of the attainment. The classification criteria are based on the following hierarchy (Ebel \& Frisbie, 1972).
$\mathrm{A}=(81-100) \%$
: very high
$\mathrm{B}=(61-80) \%$
: high
$\mathrm{C}=(41-60) \%$
: fair
$\mathrm{D}=(21-40) \%$
: low
$\mathrm{E}=(0-20) \quad \%$
: very low

The T-Score determines the qualification of each component. If the T-Score $>$ 50 , it is positive $(+)$, and if the T-Score < 50 , it is negative (-). To find out the result of each component, the number of positive $(+)$ scores and that of the negative $(-)$ ones are computed. The number of the positive scores is more or the same as that of the negative scores, the result is positive or $\sum$ the $(+)$ scores $\geq$ the $(-)$ scores $=(+)$, and vice versa, if the number of the positive scores is less than that of the negative scores, the result is negative or $\sum$ the $(+)$ scores $<$ the $(-)$ scores $=(-)$.
To find out the level of effectiveness, an analysis was made of the components of context, input, process, and product using Glickman's quadrant model (Glickman, Gordon, \& Ross-Gordon, 2001) which was divided into four quadrants (Gregory, 2004; Sahertian, 2000). If the analysis indicates that the results of all the components are positive $(+)$, then it is located in quadrant $\mathrm{I}$, meaning that the implementation is effective. On the other hand, if it shows that all of the results are negative (-) and located in quadrant IV, it means that it is not effective. If the analysis shows that one or two components have a negative (-) result, then it is located in quadrant II, and it means the implementation is effective enough. Meanwhile, if the analysis shows that three of the components are negative (-), then it is located in quadrant III, which means the implementation is less effective (Gregory, 2004).

Thus, there will be four models of the classification of the level of effectiveness of teaching at BSP, namely (1) if the CIPP position shows ++++ , then the implementation of the teaching program will fall into the effective category; (2) if the CIPP position shows - - - , then the implementation of the teaching will belong to the ineffective category; (3) if the CIPP position shows -+++ or $+t_{-}++$or $+++_{-}+$or + ++ - or ++ - or $_{-}+$- $_{-}$or $-t_{-}+$or + + - or -++ - or $+-+_{-}$, then the implementation of the teaching program will fall into the effective enough category; and (4) if the CIPP position shows + - - - or - + - or - - + or - - + then the implementation of the teaching program will fall into the less effective category.

\section{Findings and Discussion}

The result of the measurement of the components of context, input, process, and product is presented in Table 1. Based on Table 1, the data of the result of measurement of the context variable tend to center around the score of 104.72 (high). The score with the highest frequency is 104 , and the median is 105 , the highest score is 116 , 
the lowest is 89 , the standard deviation is 4.4 , with the score variation of 16.44 . The data of the input variable tend to center around the score of 142.41 (very high). The score with the highest frequency is 137 , and the median is 140 , the highest score is 167 , the lowest is 121 , the standard deviation is 8.28 , with the score variation of 68.58 . The data of the process variable show that they tend to center around 118.15 (very high). The score with the highest frequency is 112 , and the median is 119 , the highest score is 134 , the lowest is 99 , the standard deviation is 7.20 , with the score variation of 51.79 . On the other hand, the data of the product variable tend to center around the score of 14.93 (enough). The score with the highest frequency is 15 , and the median is 14.6 , the highest is 20.92 , the lowest is 11.13 , the standard deviation is 2.04 , with the score variation of 4.17 .

The results of the T-score are presented in Table 2. Based on Table 2, all the components of the context variable produce positive $(+)$ scores. It shows that the indicators that cover the teaching plan, vision, and missions, and learning environment have met the expectation. The difference between the $(+)$ score and the $(-)$ score is positive $(+)$, the score of vision and missions is positive $(+)$, and that of the learning environment is positive $(+)$. There is a match between reality and theory. Hence, in general, the context variable has supported the implementation of the teaching program. The components of the teaching plan, vision and missions, and learning environment contribute significantly to the implementation of the teaching program. The teaching plan obtains a score of $79.74 \%$ (good). The construction has followed the principles, goals, and functions of the teaching plan. An appropriate and effective teaching plan affects the success of the teaching program implementation (Majid, 2009).

Table 1. Description of the Results of the Measurement of the Components of Context, Input, Process and Product of the Teaching Implementation at BSP

\begin{tabular}{lrrrr}
\hline Statistic & Context & \multicolumn{1}{c}{ Input } & Process & Product \\
\hline $\mathrm{N}$ & 172 & 172 & 172 & 337 \\
Mean & 104.72 & 142.41 & 118.15 & 14.93 \\
Median & 105.00 & 140.00 & 119.00 & 14.6 \\
Mode & 104 & 137 & 112 & 15 \\
Std. Deviation & 4.40 & 8.281 & 7.197 & 2.04 \\
Variance & 19.38 & 68.582 & 51.790 & 4.173 \\
Range & 27 & 46 & 35 & 9.79 \\
Minimum & 89 & 121 & 99 & 1113 \\
Maximum & 116 & 167 & 134 & 20.92 \\
\hline
\end{tabular}

Table 2. Recapitulation of the Result of the T Score Analysis of the Context Variable Component

\begin{tabular}{|c|c|c|c|c|c|}
\hline \multirow[b]{2}{*}{ No } & \multirow[b]{2}{*}{ Component } & \multicolumn{3}{|c|}{ Category of Frequency } & \multirow[b]{2}{*}{ Result } \\
\hline & & $\Sigma \mathrm{f}(+)$ & $\Sigma f(-)$ & $\begin{array}{c}\Sigma f(+) \\
\%\end{array}$ & \\
\hline 1. & Teaching Plan & 106 & 66 & 61.63 & positive $(+)$ \\
\hline 2. & Vision and Missions & 89 & 83 & 51.74 & positive $(+)$ \\
\hline 3. & Learning Environment & 93 & 79 & 54.06 & positive $(+)$ \\
\hline $\begin{array}{l}\text { Total } \\
\text { Result }\end{array}$ & & 288 & 228 & & $\begin{array}{c}\text { positive (+) } \\
\text { Effective }\end{array}$ \\
\hline
\end{tabular}


The institution's vision and missions obtain a score of $88.89 \%$ (very good). The vision and missions have been able to be identified, understood, and comprehended by all of the staff members of BSP. This result supports the opinion of Hamdan (2001) that good vision and missions bring about a conducive organizational atmosphere, enthusiasm, and desire to participate in an organization. Such kind of condition encourages the staff to become more productive without any feeling of strain. Achievement learning is $83.99 \%$ (very good).

The learning environment at BSP is very good and conducive, both in the laboratory and classroom. This result supports and plays an essential role in a successful education (Purwanto, 2004). This result also confirms the finding of some researches (Latief, 2014; Menrisal, 2014), that the learning environment contributes positively and significantly to success in learning.

An appropriate and effective teaching plan directs the learning process toward the attainment of the learning objectives. Good vision and missions which are supported by a good and conducive learning environment support the staff to work more productively, so that, viewed from the components of context, the teaching program at BSP is effective.

The evaluation of the input variable covers four indicators: curriculum, semester teaching plan, infrastructure and facilities, and human resources. The recap of the result of the T-scores can be seen in Table 3 .

Based on Table 3, it is clear that the input components, including: the curriculum, semester teaching plan, and infrastruc- ture and facilities obtain negative scores. On the other hand, human resources components obtain positive scores. Not all of the indicators of the input variable meet the expectation. The components of the curriculum, semester teaching plan, infrastructure, and facilities have not met the expectation by the fact that although all the study programs have got a lesson plan for all courses. Besides, there is no guideline on how to develop the curriculum, the statements of the attainment of the learning achievement tend not to refer to the statement of the graduate's standard competencies stipulated in the national standard of higher education. The semester teaching plans which are designed by the lecturers do not satisfactorily meet the national standard of higher education.

Semester teaching plans play an important role in interactions between the students and lecturer in the learning process (Amador \& Lamberg, 2013). Furthermore, semester teaching plans are efforts to estimate what actions will be made by the lecturers in the teaching activities. When they are designed well, one can guarantee that half of the activities have been completed (Mulyasa, 2008). The writing of the teaching plans should meet the principles of the semester teaching plans and be implemented in accordance with the characteristics of the courses as well as the students. The procedure of how to write teaching plans have been stipulated in the Regulation of the Minister of Research, Technology, and Higher Education No. 44 of 2015 on the national standard of higher education.

Table 3. Recapitulation of the Result of the T-Score Analysis of the Input Variable

\begin{tabular}{llcccc}
\hline \multirow{2}{*}{ No } & \multicolumn{1}{c}{ Component } & $\boldsymbol{\Sigma} \mathbf{f}(+)$ & $\boldsymbol{\Sigma} \mathbf{f}(-)$ & $\boldsymbol{\Sigma} \mathbf{f}(+)$ & Result \\
& & 83 & 89 & 48.26 & negative $(-)$ \\
\hline 1 & Curriculum & 81 & 91 & 47.09 & negative $(-)$ \\
2 & Semester Teaching Plan & 80 & 92 & 46.51 & negative $(-)$ \\
3 & Infrastructure and Facilities & 90 & 82 & 52,32 & positive $(+)$ \\
4 & Human resourcees & 334 & 354 & & negative $(-)$ \\
& Total & & & & Less effective \\
\hline
\end{tabular}


The infrastructure and facilities obtain a negative score. They have not met the expectation, because, in every department, students have not got the printed learning materials in the form of textbooks and job sheets as the guides for them to learn. Part of the learning materials is available online through BSP e-learning, but it is difficult to access this facility, both by the students and the lecturers. The media that support the curriculum, such as LCD projector, in every classroom, do not work well.

The educational infrastructure and facilities are required in teaching and learning process, both movable and fixed ones. This component is one of the essential supports in implementing the teaching process. If the infrastructure and facilities are available, adequate, and made use of effectively, they can contribute to the students' academic achievement. Thus, adequate infrastructure and facilities are the keys to lecturers' performance success. Some research findings (Akomolafe \& Adesua (2016); Ayeni \& Adelabu (2012); Jannah \& Sontani (2018)) prove that infrastructure and facilities affect and contribute significantly to the lecturers' performances, the students' learning motivation, and academic achievement. Hence, when the infrastructure and facilities are not adequate or have not been used effectively, they can become a hindrance to the lecturers' performances and the improvement of the students' achievement.

The human resources component obtains a positive score. It means that human resources, particularly the lecturers at BSP, have met the expectation. They have contributed positively in implementing the teaching program. It supports the finding in the study conducted by Heyneman and Loxley in 1983 (Supriadi, 2005; Widoyoko \& Rinawati, 2012), that teachers give a contribution to learning achievement by $34 \%$. Sudjana (2002) states that the teacher's performance influences $6.6 \%$ of the learning achievement. Thus, human resources correlate positively with the quality of the teaching process. The input variable does not support the implementation of the teaching program implementation at BSP since the input components like semester teaching plans, and infrastructure and facilities do not contribute satisfactorily to the teaching program implementation.

The evaluation of the process variable covers the teaching contents, the teaching and learning activities, and assessment. The recap of the result of the $\mathrm{T}$-score analysis is presented in Table 4. Based on Table 4, the analysis of the $\mathrm{T}$-score of the process variable components (contents, teaching activities) obtains a positive score, while the assessment component obtains a negative score. The contents and teaching activities have met the expectation and contributed to the process variable. However, the assessment component has not met the expectation and contributed less satisfactorily to the process variable. In addition, $51.4 \%$ of the assessment the lecturers implemented has not met the evaluation standard of teaching outlined in the Regulation of the Minister of Research, Technology, and Higher Education No. 44 of 2015, especially concerning the principles, techniques,

Table 4. Recapitulation of the Result of the Analysis of the Components of the Process Variable

\begin{tabular}{|c|c|c|c|c|}
\hline \multirow[b]{2}{*}{ Component } & \multicolumn{3}{|c|}{ Category of Frequency } & \multirow[b]{2}{*}{ Result } \\
\hline & $\Sigma \mathrm{f}(+)$ & $\Sigma \mathrm{f}(-)$ & $\begin{array}{c}\Sigma f(+) \\
\%\end{array}$ & \\
\hline Content & 92 & 80 & 53.48 & positive $(+)$ \\
\hline Learning activities & 101 & 71 & 58.72 & positive $(+)$ \\
\hline Assessment & 83 & 89 & 48.6 & negative $(-)$ \\
\hline Total & 276 & 240 & & positive $(+)$ \\
\hline Result & & & & Effective enough \\
\hline
\end{tabular}


and instruments as well as the procedures of assessment. Assessment is done separately with the teaching activities, namely in the middle of the semester and the end of the semester. This condition is in contradiction to the statement of Badmus (2007) and Sani (2016) that an implementation of a proper assessment should follow a good teaching quality. Assessment is an integral part of the teaching process, and should be implemented in integration with the teaching process and conducted continually.

The contents and activities of good teaching, when it is unsupported by a good and well-planned evaluation, will make the teaching ineffective. In support of the findings of Darma (2018) and Darma, Candiasa, Sadia, and Dantes (2018), learning achievement is significantly influenced by an evaluation system implemented. Hence, viewed from the input component, the teaching program at BSP is sufficient enough.

The evaluation of the product variable covers the academic area of the students' learning achievements as shown by cumulative grade point average (GPA) and non-academic achievement. The recap of the result of the T-score of the product components is presented in Table 5 .
Based on Table 5, all of the components of the product obtain a negative score. In general, the product variable does not support the teaching implementation at BSP. The academic and the non-academic components have not met the expectation and contributed less significantly to the product variable. The objective of the teaching program at BSP has not attained optimally. Yusuf (2015) explains that product evaluation is done at the end of an activity and is intended to measure the achievement of the objectives that have been determined before based on a particular standard or criteria. This finding is supported by theories (Arikunto, 2009; Stufflebeam \& Shinkfield, 2007) and findings (Warju, 2016; Zhang et al., 2011) that the final evaluation (product) relates information on the final achievement to the objectives, context, input, and process that have been implemented before it.

The failure to achieve the objectives of teaching at BSP is since the teaching is less supported by a good and appropriate curriculum, semester teaching plan, and infrastructure as well as facilities suitable for students' needs. The recap of the T-scores related to the context, input, process, and product variables is presented in Table 6 .

Table 5. Recapitulation of the Result of the Analysis of the Components of the Product Variable

\begin{tabular}{lcccc}
\hline Component & \multicolumn{4}{c}{ Category of Frequency } \\
& $\boldsymbol{\Sigma} \mathbf{f} \mathbf{f}(+)$ & $\boldsymbol{\Sigma} \mathbf{f}(-)$ & $\begin{array}{c}\boldsymbol{\Sigma} \mathbf{f} \mathbf{( + )} \\
\mathbf{( \% )}\end{array}$ & Result \\
\hline Academic & 146 & 191 & 43.32 & negative (-) \\
$\quad$ Non-academic & 166 & 171 & 49.26 & negative (-) \\
\hline Total & 312 & 362 & negative (-) \\
Result & & & & Ineffective \\
\hline
\end{tabular}

Table 6. Relation Among the Variables of Context, Input, Input and Product

\begin{tabular}{|c|c|c|c|c|c|c|c|}
\hline \multirow{3}{*}{ Variable } & \multicolumn{7}{|c|}{ Category of Frequency } \\
\hline & \multicolumn{2}{|c|}{$f(+)$} & \multicolumn{2}{|c|}{$f(-)$} & \multirow[b]{2}{*}{$\begin{array}{c}\text { Diff. } \\
\%\end{array}$} & \multirow[b]{2}{*}{ Result } & \multirow[b]{2}{*}{ Remarks } \\
\hline & $\Sigma f(+)$ & $\%$ & $\Sigma f(-)$ & $\%$ & & & \\
\hline Context & 89 & 51.74 & 83 & 48.26 & 3.48 & + & Positive \\
\hline Input & 78 & 45.33 & 94 & 54.67 & -9.34 & - & Negative \\
\hline Process & 104 & 60.47 & 68 & 39.53 & 20.94 & + & Positive \\
\hline Product & 166 & 49.26 & 171 & 50.74 & -1.48 & - & Negative \\
\hline
\end{tabular}

Notes: $\mathrm{T} \geq 50$ means that the component $=(+) ; \mathrm{T}<50$ means that the score component $=(-)$. 


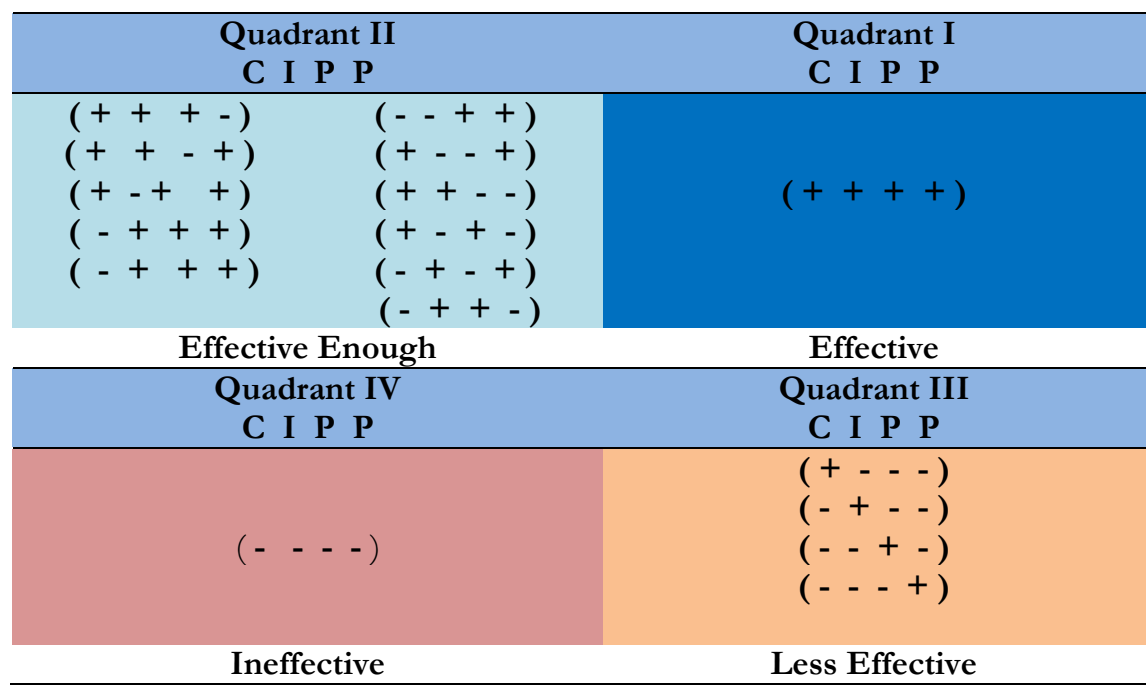

Figure 1. Glickman's Quadrants of the Effectiveness of the Implementation of Teaching at BSP

Table 6 shows that the T-score of the context variable is positive $(+)$, that of input is negative $(-)$, that of the process is positive $(+)$, and that of the product is negative $(-)$. The whole the scores are $(+-+-)$. These results are verified into the Glickman quadrant, as shown in Figure 1.

The pattern of the CIPP scores of + + - in Figure 1 falls into Quadrant II. This position shows that the condition of teaching at BSP is sufficient enough. It is because, simultaneously, the variables of context, input, process, and product have given different supports to the effectiveness of the teaching. The context and process have strong supports, while the input and product have weak supports. It supports the result of an evaluation by Gunung and Darma (2018) that the implementation of the teaching program at BSP, viewed from the variables of context, input, process, and the product, is sufficient enough. It confirms the studies by Kavgaoglu and Alci (2016) and Riptiani, Manuaba, and Putra (2015) that the effectiveness of each component of context, input, process, and product influences the level of effectiveness of the program evaluated.

The result of the evaluation agrees with Kaufman and Thomas (in Mukhadis, 2013) that the aspect of the context in the program evaluation can affect the process of the implementation and attainment of the objectives of a program that has been designed. Komariah and Triatna (2005) state that effectiveness is a dimension of the objective of the management that focuses on the result, objectives, and target expected. A competent institution of higher education is an institution that determines its success in terms of input, process, context, and product characterized by the high quality of the components of the system. Arikunto (2009) states that the CIPP model of evaluation sees the program evaluated as a system. The integration of context, input, and process supports and at the same time, influences the product or output. The level of effectiveness of each component influences the effectiveness of the program. The presence of constraints in each component will, at the same time, influence the effectiveness of the program. Hence, the level of effectiveness of the teaching program at BSP is effective enough because of the presence of constraints in the components of context, input, and product.

The effectiveness of the teaching at BSP viewed from context is effective. The factors that are related to the context variable are teaching plan, vision and missions, learning environment which has met the expectation and contributed to the implementation of the teaching program. There is no constraint on the context variable. In relation to this absence of constraint, the 
institution needs to maintain and even to improve the effectiveness of the context both in relation to the teaching plan, vision, and missions and learning environment and to enhance the effectiveness of the implementation of the teaching program.

The planning of the teaching program is something that needs much improvement. The improvement of the quality of the teaching can be started from the teaching plan (Dwiyogo, 2018) since the teaching plan serves as the reference for the lecturers in implementing the teaching activities that are more oriented, which will proceed efficiently and effectively. Işman (2011) states that the planning of a teaching program is an essential stage in improving the quality of teaching. Its design has to be based on active learning. The success of a teaching process is determined by a mature plan. When a plan is made well, it means that half of the success has been attained, the rest lies in its implementation.

The implementation of the teaching program at BSP viewed from the input is low active. This condition is caused by the fact that some of its components are not effective. The curriculum, semester teaching plan, infrastructure, and facilities do not contribute significantly to the implementation of the teaching program. Thus, these components have some constraints in the input variable.

The constraints that are originated from the curriculum include the contents presented, namely the relation between the graduates' learning achievements and the course learning achievements. The learning activities that are designed do not support the graduates' learning achievements and the course learning achievements, the statements of the indicators of achievement in the course learning achievements are not clear, and the types of evaluation implemented are still oriented toward the product evaluation.

The constraint which is originated from the semester teaching plan is related to its implementation. The level of the impracticality of the semester teaching plan is still high or $69.5 \%$. In implementing the teaching process, the lecturers tend not to bring the semester teaching plans that they have prepared. On the other hand, the semester teaching plan is a projection of the activities which will be done by the lecturer with the students in the teaching and learning process in the classroom and is an integral part that cannot be separated from the teaching. Every lecturer who will teach should write a semester teaching plan first. A well written semester teaching plan can help the lecturer in implementing the teaching in the classroom effectively and efficiently.

The curriculum, as a design, consists of four elements: learning achievements (learning objectives), materials that have to be acquired, teaching strategies to achieve the objectives, and the evaluation system to evaluate the achievement of the objectives. The statement of the compulsory graduate's learning achievement refers to the description of the learning achievements of the Indonesian National Qualifications Framework graduates, and the achievements are equivalent to the level of qualification at the Indonesian National Qualifications Framework. The statement contains three elements, namely attitude, knowledge, and skills, and the latter is divided into general and specific skills by the graduates of the institute of higher education (Regulation of the Minister of Research, Technology, and Higher Education No. 44, 2015).

On the other hand, the constraints also come from the infrastructure and facilities as well as the media. The e-learning facility does not function maximally. The textbooks as the handbooks for the lecturers and students do not satisfactorily meet the students' needs. In this context, the institution needs to improve the effectiveness of the input concerning the curriculum, semester teaching plan, infrastructure and facilities, and human resources so that it can enhance the effectiveness of teaching.

The process variable, in general, has supported the implementation of the teach- 
ing program. The effectiveness of the teaching program at BSP viewed from the process component is effective. The factors that are related to the process variable are the contents of the teaching program, teaching activities, and assessment which have contributed to the implementation of the teaching program. However, there is a component that is still less effective, namely evaluation. The assessment component does not contribute much to the teaching implementation. The assessment system implemented has not met the expectation. It has not met the standard of teaching evaluation and become a constraint that is originated from the process variable.

The standard of teaching assessment is the minimal criterion of process and product evaluation in the effort of meeting the graduate's learning achievement. The principles of assessment include educative, authentic, objective, accountable, and transparent principles that are used integrated. The authentic principle orientations are toward a sustainable learning process and learning achievement, which reflect the students' ability (Regulation of the Minister of Research, Technology, and Higher Education No. 44, 2015).

Assessment and teaching are two activities that support each other. Improvement in teaching quality can be made by improving its evaluation system (Mardapi, 2014). A proper assessment system will encourage the lecturers in determining a good teaching strategy in motivating students to learn better.

In this context, the institution needs to maintain and even to improve the effectiveness of the process, especially in relation to the implementation of the assessment so that in the end, the teaching program can be improved. To improve the quality of education, one needs to improve the assessment system implemented. Good-quality teaching should be followed by the implementation of a good assessment (Sani, 2016).

The teaching at BSP viewed from the product component is not effective since, in general, the product variable less satisfacto- rily supports the teaching program implementation. The components or academic and non-academic learning achievements contribute less satisfactorily to the implementation of the teaching program. Hence, these components become the constraints originated from the product variable in the teaching program implementation.

The less satisfactory contribution of the learning achievement in the academic and non-academic activities to the effectiveness of the teaching program is caused by the ineffectiveness of the input variable or curriculum, semester teaching plan, and also infrastructure and facility components. Another cause of less effectiveness comes from the evaluation component. Therefore, these components became the constraints in the product variable in supporting the teaching program implementation. In relation to these constraints, the institution needs to improve the effectiveness of the product, thereby the effectiveness of the teaching program.

\section{Conclusion}

The teaching program at BSP viewed from the interrelatedness of context, input, process, and product components is effective enough. The constraints in the teaching implementation at BSP consist of those in the context, input, process, and product components. The context variable consists of the teaching plan. The input variable consists of the curriculum, the semester teaching plan, and the infrastructure and facilities. The process variable consists of the assessment system. The product variable consists of the quality of learning achievement, both academic and nonacademic.

It is recommended to the decisionmakers at BSP to (1) review the implemented curriculum, especially concerning the statement of learning achievement; (2) adapt the activities of teaching in the classroom and laboratory to the semester teaching plan that has been written; (3) encourage the lecturers to prepare printed learning materials according to the students' 
learning needs; and (4) change the evaluation system implemented into the evaluation system oriented to the process as stipulated in the Regulation of the Minister of Education and Culture No. 49 of 2014 on the National Standard of Higher Education.

\section{Acknowledgment}

The researchers would like to express their gratitude to the Directorate General of the Strengthening of Research and Development, the Ministry of Research, Technology, and Higher Education who financed this research.

\section{References}

Akomolafe, C. O., \& Adesua, V. O. (2016). The impact of physical facilities on students' level of motivation and academic performance in senior secondary schools in South West Nigeria. Journal of Education and Practice, 7(4), 38-42. Retrieved from https://iiste.org/Journals/index.php /JEP/article/view/28745

Amador, J., \& Lamberg, T. (2013). Learning trajectories, lesson planning, affordances, and constraints in the design and enactment of mathematics teaching. Mathematical Thinking and Learning, 15(2), 146-170. https://doi. org/10.1080/10986065.2013.770719

Ariawan, I. P. W., Sanjaya, D. B., \& Divayana, D. G. H. (2016). An evaluation of the implementation of practice teaching program for prospective teachers at Ganesha University of Education based on CIPP-forward chaining. International Journal of Advanced Research in Artificial Intelligence (IJARAI), 5(2), 1-5. https: //doi.org/10.14569/IJARAI.2016.05 0201

Arikunto, S. (2009). Evaluasi program pendidikan. Jakarta: Bumi Aksara.

Arikunto, S. (2012). Dasar-dasar evaluasi pendidikan. Jakarta: Bumi Aksara.
Ayeni, A. J., \& Adelabu, M. A. (2012). Improving learning infrastructure and environment for sustainable quality assurance practice in secondary schools in Ondo State, South-West, Nigeria. International Journal of Research Studies in Education, 1(1), 61-68. https: //doi.org/10.5861/ijrse.2012.v1i1.20

Badmus, G. A. (2007). Changing nature of technical and vocational education and students' assessment methods. Retrieved from https://www.iaea.info/abstract _files/

Darma, I. K. (2018). Improving mathematical problem solving ability through problem-based learning and authentic assessment for the students of Bali State Polytechnic. Journal of Physics: Conference Series, 953, 012099. https://doi.org/10.1088/1742-6596/ 953/1/012099

Darma, I. K., Candiasa, I. M., Sadia, I. W., \& Dantes, N. (2018). The effect of problem based learning model and authentic assessment on mathematical problem solving ability by using numeric ability as the covariable. Journal of Physics: Conference Series, 1040, 012035. https://doi.org/10.1088/17 42-6596/1040/1/012035

Dwiyogo, W. D. (2018). Pembelajaran berbasis blended learning. Depok: PT Rajagrafindo Persada.

Ebel, R. L., \& Frisbie, D. A. (1991). Essentials of educational measurement (5th ed.). Englewood Cliffs, NJ: Prentice-Hall.

Ebel, R. L., \& Frisbie, D. A. (1972). Essentials of educational measurement. Englewood Cliffs, NJ: Prentice-Hall.

Forouzandeh, E., Riazi, A. M., \& Sadighi, F. (2008). TEFL program evaluation at master's level in Iran. Teaching English Language (Teaching English Language and Literature Society of Iran), 2(6), 71-100. Retrieved from https://www.sid.ir/ en/journal/ViewPaper.aspx?ID=135 337

The effectiveness and constraints of learning... - 
Glickman, C. D., Gordon, S. P., \& RossGordon, J. M. (2001). Supervision and instructional leadership: A developmental approach (5th ed.). Needham Heights, MA: Allyn \& Bacon.

Gregory, R. J. (2004). Psychological testing: History, principles, and applications. Boston, MA: Allyn \& Bacon.

Gronlund, N. E., \& Linn, R. L. (1990). Measurement and evaluation in teaching (6th ed.). New York, NY: Macmillan.

Gunung, I. N., \& Darma, I. K. (2018). Evaluation of learning programs at Bali State Polytechnic (BSP). Proceedings of the International Conference on Science and Technology (ICST 2018), 1129-1134. https://doi.org/10.2991/ icst-18.2018.228

Hamdan, Y. (2001). Pernyataan visi dan misi perguruan tinggi. Mimbar: Jurnal Sosial Dan Pembangunan, 17(1), 90-103. https://doi.org/10.29313/mimbar.v1 $7 \mathrm{i} 1.34$

Hasan, A., Yasin, S. N. T. M., \& Yunus, M. F. M. (2015). A conceptual framework for mechatronics curriculum using Stufflebeam CIPP evaluation model. Procedia - Social and Behavioral Sciences, 195, 844-849. https://doi.org/10.1016/j.sbspro.201 5.06 .324

Issman, A. (2011). Instructional design in education: New model. Turkish Online Journal of Educational Technology TOJET, 10(1), 136-142. Retrieved from http://www.tojet.net/articles/ v10i1/10114.pdf

Jannah, S. N., \& Sontani, U. T. (2018). Sarana dan prasarana pembelajaran sebagai faktor determinan terhadap motivasi belajar siswa. Jurnal Pendidikan Manajemen Perkantoran (JPManper), 3(1), 63-70. Retrieved from https://ejournal.upi.edu/index. $\mathrm{php/jpmanper/issue/view/952}$

Kavgaoglu, D., \& Alci, B. (2016). Application of context input process and product model in curriculum evaluation: Case study of a call centre. Educational Research and Reviews, 11(17), 1659-1669. https://doi.org/10.5897/ ERR2016.2911

Komariah, A., \& Triatna, C. (2005). Visionary leadership menuju sekolah efektif. Jakarta: PT Bumi Aksara.

Latief, A. (2014). Pengaruh lingkungan sekolah terhadap hasil belajar Pendidikan Kewarganegaraan pada peserta didik di SMK Negeri Paku Kecamatan Binuang Kabupaten Polewali Mandar. Pepatudzu: Media Pendidikan Dan Sosial Kemasyarakatan, 7(1), 13-26. https://doi.org/ 10.35329/fkip.v7i1.11

Majid, A. (2009). Perencanaan pembelajaran. Bandung: PT Remaja Rosdakarya.

Mardapi, D. (2012). Pengukuran, penilaian, dan evaluasi pendidikan. Yogyakarta: Nuha Medika.

Mardapi, D. (2014). Authentic assessment. The Paper Presented at HEPI Conference. Denpasar, Bali.

Menrisal, M. (2014). Kontribusi lingkungan belajar terhadap hasil belajar sistem operasi siswa kelas X Teknik Komputer dan Jaringan (TKJ) di Sekolah Menengah Kejuruan (SMK) Negeri 3 Pariaman semester ganjil tahun ajaran 2014/2015. Jurnal KomTekInfo Fakultas Ilmu Komputer, 1(2), 77-83. Retrieved from http://lppm.upiyptk.ac.id/kom tekinfo/index.php/KOMTEKINFO /article/download/10/10

Mukhadis, A. (2013). Evaluasi program pembelajaran bidang teknologi. Malang: Bayumedia.

Mulyasa, M. (2008). Menjadi guru profesional. Bandung: PT Remaja Rosdakarya.

Nasution, M. N. (2001). Manajemen mutu terpadu (Total quality management). Jakarta: Ghalia Indonesia.

Purwanto, M. N. (2004). Psikologi pendidikan. Bandung: PT Remaja Rosdakarya. 
Regulation of the Minister of Education and Culture No. 49 of 2014 on the National Standard of Higher Education. , (2014).

Regulation of the Minister of Research, Technology, and Higher Education No. 44 of 2015 on the National Standard of Higher Education., (2015).

Riptiani, K. M., Manuaba, I. B. S., \& Putra, M. (2015). Studi evaluasi implementasi Kurikulum 2013 ditinjau dari CIPP pada sekolah dasar negeri di wilayah pedesaan Kabupaten Badung. Mimbar PGSD Undiksha, 3(1). https://doi.org/10.23887/jjpgsd .v3i1.5015

Sahertian, P. A. (2000). Konsep dasar dan teknik supervisi pendidikan dalam rangka pengembangan sumber daya manusia. Jakarta: Rineka Cipta.

Sani, R. A. (2016). Penilaian autentik. Jakarta: PT Bumi Aksara.

Stufflebeam, D. L. (2003). The CIPP model for evaluation. In T. Kellaghan \& D. L. Stufflebeam (Eds.), International Handbook of Educational Evaluation (vol. 9, pp. 31-62). Dordrecht: Springer.

Stufflebeam, D. L., \& Coryn, C. L. S. (2014). Evaluation, theory, models, and applications (2nd ed.). San Francisco, CA: John Wiley \& Sons.

Stufflebeam, D. L., \& Shinkfield, A. J. (2007). Evaluation theory, models, \& applications. San Francisco, CA: JosseyBass.

Sudjana, N. (2002). Dasar-dasar proses belajar dan mengajar. Bandung: Sinar Baru Algesindo.

Sudjana, N. (2012). Penilain hasil proses belajar mengajar. Bandung: Remaja Rosda Karya.
Sugiyono. (2012). Metode penelitian pendidikan: Penelitian kuantitatif, kualitatif, dan R\&D. Bandung: Alfabeta.

Sukardi, S. (2014). Evaluasi program pendidikan dan pelatiban. Jakarta: Bumi Aksara.

Supriadi, D. (2005). Mengangkat citra dan martabat guru. Yogyakarta: Adicita Karya Nusa.

Waluyati, I. (2012). Evaluasi program pembelajaran ilmu pengetahuan sosial SMP/MTs di Kota Bima. Jurnal Penelitian Dan Evaluasi Pendidikan, 16(1), 260-280. https://doi.org/ 10.21831/pep.v16i1.1117

Warju, W. (2016). Educational program evaluation using CIPP model. Innovation of Vocational Technology Education, 12(1), 36-42. https://doi. org/10.17509/invotec.v12i1.4502

Widoyoko, S. E. P., \& Rinawati, A. (2012). Pengaruh kinerja guru terhadap motivasi belajar siswa. Cakrawala Pendidikan, 31(2), 278-289. https:// doi.org/10.21831/cp.v5i2.1563

Yusuf, A. M. (2015). Asesmen dan evaluasi pendidikan: Pilar penyedia informasi dan kegiatan pengendalian mutu pendidikan. Jakarta: Prenada Media Group.

Zhang, G., Zeller, N., Griffith, R., Metcalf, D., Williams, J., Shea, C., \& Misulis, K. (2011). Using the context, input, process, and product evaluation model (CIPP) as a comprehensive framework to guide the planning, implementation, and assessment of service-learning programs. Journal of Higher Education Outreach and Engagement, 15(4), 57-83. Retrieved from https://openjournals.libs.uga. edu/jheoe/article/view/901 